\title{
Possible role of bacterial and viral infections in miscarriages
}

\author{
Mihaela Matovina, M.Sc. ${ }^{\text {a }}$ \\ Koraljka Husnjak, M.Sc. ${ }^{a}$ \\ Nina Milutin, B.Sc. ${ }^{a}$ \\ Srecko Ciglar, M.D., Ph.D. ${ }^{b}$ \\ Magdalena Grce, Ph.D. ${ }^{a}$
}

“Rudjer Boskovic” Insitute, Division of Molecular Medicine, Bijenicka cesta 54, HR-10002 Zagreb, Croatia

Received April 9, 2003; revised ... and accepted ...

Supported by grants (number: 044001 and 098104) from Croatian Ministry of Science and Technology, Zagreb, Croatia.

Reprint requests: Magdalena Grce, Ph.D., "Rudjer Boskovic" Institute, Bijenicka cesta 54, HR-10002 Zagreb, Croatia.

(FAX: +38514561010; e-mail: grce@irb.hr).

${ }^{a}$ Rudjer Boskovic" Insitute, Division of Molecular Medicine, Bijenicka cesta 54, HR-10002 Zagreb, Croatia.

${ }^{\mathrm{b}}$ University Hospital "Merkur", Departmant of Obstetrics and Gynecology, Zajceva 19, HR-10000 Zagreb, Croatia.

\section{Capsule}

With the use of polymerase chain reaction, human papillomavirus and Chlamydia trachomatis were detected in $7.4 \%$ and $1 \%$ of placental samples from miscarriages, respectively. 


\section{Structured abstract and key words}

Objective: In order to determine the role of infections in miscarriages, chorionic villi from aborted material were subjected to cytogenetic evaluation and analysed for the presence of Chlamydia trachomatis, Ureaplasma urealyticum, Mycoplasma hominis, human cytomegalovirus (HCMV), adeno-associated virus (AAV) and human papillomaviruses (HPV).

Design: Retrospective study.

Setting: University hospital and academic research institution.

Main Outcome Measure(s): Karyotyping and detection of bacterial and viral DNA by means of polymerase chain reaction (PCR) in placenta specimens.

Result(s): In 54 (50\%) of 108 samples the karyotype was normal, in 38 (35\%) samples it was abnormal and in $16(15 \%)$ samples karyotype was undetermined. No U. urealyticum, $M$. hominis, HCMV or AAV 2 DNA was detected, while $C$. trachomatis DNA was detected in one $(1 \%)$ and HPV DNA in eight (7\%) samples. No significant correlation of HPV positive findings with karyotype status was established.

Conclusion(s): Our findings do not support a role of $C$. trachomatis, U. urealyticum, $M$. hominis, HCMV and AAV infections in miscarriages during the first trimester of pregnancy. However, further investigation should be made to determine a possible involvement of HPVs in the development of genetic abnormalities of the fetus, and in miscarriages.

Key Words: Miscarriage, karyotyping, placenta, PCR, bacterial infections, viral infections 


\section{INTRODUCTION}

Miscarriages are considered to be the most common complication in pregnancy. The incidence of miscarriages in clinically established pregnancies (over sixth gestational week) is approximately 12 to $15 \%$ (1). Recurrent (three or more consecutive) miscarriages represent a special problem resulting with serious physical as well as psychological damage to women. Unfortunately, they occur quite often, in 1 out of 300 pregnancies (2).

Several possible causes of miscarriage have been considered, the major ones being genetic abnormalities of the fetus. It has been established that more than $50 \%$ of miscarried fetuses are genetically abnormal $(3,4)$. Apart from that, other causes of miscarriage could be anatomical anomalies of the mother, endocrine and immunological causes, different environmental factors, such as exposure to various toxic substances (caffeine, nicotine), and infections (5-7). According to Garcia-Enguinados et al. (8), only genetic and anatomical abnormalities have been proven as direct causes of miscarriages, whereas intrauterine infections have been established as a cause of premature rupture of fetal membranes and preterm labor, and their role in miscarriage is still not completely clear. Several studies have confirmed the role of infections as a cause of miscarriage, especially during the second trimester of pregnancy, but the role of infection in first trimester miscarriages is still questionable (9).

Since the main route of infection to placenta and fetus is from vagina and cervix, most studies were oriented on an attempt to find an association between miscarriage and abnormal bacterial flora in the lower genital tract, vagina and cervix, respectively. Gardnerella vaginalis and Mycoplasma hominis both cause vaginitis and are often found in mixed infections as a cause of amnionitis, whereas Ureaplasma urealyticum is found as a sole cause of amnionitis $(10,11)$. These pathogens are also considered as a cause of preterm labor, beside Escherichia coli, enterococci, staphylococci and group B streptococci (12).

A microorganism should have access to the intrauterine surroundings in order to cause inflammatory reaction of endometrium or fetal tissues responsible for a miscarriage. Infectious agents present inside the uterus can cause infections between decidual tissue and fetal membranes (amnion and chorion), inside placenta, in the amniotic fluid (amnionitis) or in the umbillical cord (funisitis). Infections of the placenta are rare and the most common causative agents found are Treponema pallidum, Mycobacterium tuberculosis, chlamydias, mycoplasmas, Rubella virus, human cytomegalovirus (HCMV), herpes simplex virus (HSV), Toxoplasma gondii and Candida albicans $(13,14)$. However, it has not been established whether such infections cause miscarriage.

Witkin et al. (15) established that Chlamydia trachomatis could provoke miscarriage due to strong immunological reaction to the specific bacterial protein. Moreover, $C$. trachomatis infections of the cervix have been associated with second trimester abortions and premature membrane rupture (16).

It is well established that mycoplasmas are prevalent in the lower genital tract of pregnant women, but they are also quite common in the genitourinary tract of sexually active men and women in general (17). Some studies suggest an association of mycoplasma infection with sporadic and recurrent miscarriages $(18,19)$.

HCMV is the most common congenital infection in humans, with the incidence of $1 \%$ of all live births (20). However, there is no consensus about HCMV involvement in spontaneous abortions $(21,22)$. 
Adeno-associated virus (AAV), which is not a priori associated with diseases in humans (23), has been found in human blood cells, biopsies and cervical epithelial cell brushings, endometrium and material from spontaneous abortion which indicates its possible role in miscarriage induction (24-27).

The role of HPV in the development of cervical carcinoma is well-established (28), however its involvement in the development of miscarriage is also under consideration (29, 30).

Herein, we investigated the association of first trimester miscarriages with the placental presence of suspected pathogens involved in the induction of miscarriages, i.e. $U$. urealyticum, M. hominis, C. trachomatis, HCMV, AAV and HPV.

\section{MATERIAL AND METHODS}

Patients

Hundred and eight Croatian women attending the Clinic of Gynecology and Obstetrics in University Hospital "Merkur" (Zagreb, Croatia) were involved in this study. Each woman was admitted to the hospital because of the threatening miscarriage. All of them were informed about the following therapeutic and diagnostic procedures and agreed by signed consent. They were 18 to 46 years old (mean age 32 years), and the gestational age at which miscarriage occurred was between 4 and 19 weeks (mean gestational age 10 weeks). Their uterine cervices were normal and chronic or hereditary diseases were excluded.

The Ethical Board of the University Hospital "Merkur" and the Ethical Board of the "Rudjer Boskovic" Institute approved further analysis presented in this study.

Tissue sampling

Placental tissue was collected by curettage, cleaned of decidual tissue, rinsed in HAMS F10 medium (Gibco BRL) and dissected under a stereoscopic microscope. Chorionic villi were used to determine the karyotype of the fetuses and DNA was isolated from the placental tissue in order to investigate the presence of bacterial and viral infections by means of polymerase chain reaction (PCR). Karyotyping was performed at the Laboratory for cytology and clinical genetics, University Hospital "Merkur" (Zagreb, Croatia) while the molecular analyses were performed at the Laboratory of Molecular Oncology, Division of Molecular Medicine, "Rudjer Boskovic” Institute (Zagreb, Croatia).

Cytogenetic analysis

The direct method for karyotyping chorionic villi was performed according to Singer and Profeta (31). Briefly, chorionic villi were cultivated for 1 to 3 days at $37^{\circ} \mathrm{C}$. An hour and 30 minutes before proceeding with slide preparations, $0.01 \mathrm{mg} / \mathrm{ml}$ of Colchicine (Fluka) was added to the medium to stop the cells in the metaphase of mitosis. The tissue was then removed from the medium and treated with hypotonic and fixative solution (3:1 methanol and acetic acid) in order to preserve cells in their "swollen" state. After the removal of fixative, a few drops of $60 \%$ acetic acid were added to the tissue to cause cell dissociation. One drop of the cell suspension was placed on each slide and spread across it. The chromosomes were Qand G-banded, which enabled their identification and analysis. Fifteen metaphases of each sample were analysed under the microscope and at least three metaphases were photographed and subjected to further analysis in order to determine the chromosome number, the structural chromosomal abnormalities and, finally, the karyotype. 
DNA isolation

The placenta samples were resuspended in lysis buffer $(10 \mathrm{mM}$ Tris-HCl, $\mathrm{pH} \mathrm{7.5,} 1$ mM EDTA, $\mathrm{pH} 7.9,0.5 \% \mathrm{SDS})$ and treated overnight at $37^{\circ} \mathrm{C}$ with proteinase $\mathrm{K}(100 \mu \mathrm{g} / \mathrm{ml})$. The DNA was isolated by a phenol and chloroform extraction followed by ethanol precipitation, and dissolved in tridistillated sterile water, according to Sambrook et al. (32).

Polymerase chain reaction (PCR)

Each DNA sample was subjected to several PCR reactions in order to amplify DNA of U. urealyticum, M. hominis, C. trachomatis, HCMV, AAV 2 and HPVs. Prior to PCR analysis of DNA samples for the presence of different microorganisms, primer set PC04/GH20 was used to amplify part of the $\beta$-globin gene in order to exclude possible presence of inhibitors of the PCR and to optimise sample DNA concentration (33).

The detection of $U$. urealyticum and M. hominis was done by semi-nested PCR according to Abele-Horn et al. (34). Primer pairs U4/U5 and U4/U9 (Table 1) were used to amplify part of the $U$. urealyticum urease gene, while primer pairs M1/M2 and RNAH3/M2, complementary to the part of $M$. hominis rrn B operon of the 16S rRNA gene (Table 1), were used for the detection of $M$. hominis. The reaction mixture $(20 \mu \mathrm{l})$ consisted of $10 \mathrm{mM}$ Tris$\mathrm{HCl}$ ( $\mathrm{pH} 8.3$ ), $50 \mathrm{mM} \mathrm{KCl}, 1.5 \mathrm{mM} \mathrm{MgCl}_{2}, 0.1 \mathrm{mM}$ of each dNTP, $0.5 \mu \mathrm{M}$ of each primer, approximately $100 \mathrm{ng}$ of each DNA and $0.4 \mathrm{U}$ of a thermostable AmpliTaq DNA polymerase (Roche). PCR reactions were performed for 40 cycles of denaturation $\left(95^{\circ} \mathrm{C}, 30 \mathrm{~s}\right)$, annealing $\left(46^{\circ} \mathrm{C}, 30 \mathrm{~s}\right.$ for $U$. urealyticum; $45^{\circ} \mathrm{C}, 30 \mathrm{~s}$ for $M$. hominis) and elongation $\left(72^{\circ} \mathrm{C}, 45 \mathrm{~s}\right)$. DNA extracted from cultured $U$. urealyticum and M. hominis (kindly provided by Dr. Z. Persic, Zagreb, Croatia) was used as positive control.

Detection of $C$. trachomatis was done according to Loeffelholz et al. (35). Primer pair CP24/CP27 (Table 1) was used to amplify part of $C$. trachomatis cryptic plasmid. The reaction mixture $(20 \mu \mathrm{l})$ consisted of $10 \mathrm{mM}$ Tris- $\mathrm{HCl}(\mathrm{pH} 8.3), 50 \mathrm{mM} \mathrm{KCl}, 1.5 \mathrm{mM} \mathrm{MgCl}_{2}$, $0.1 \mathrm{mM}$ of each dNTP, $0.5 \mu \mathrm{M}$ of each primer, approximately $100 \mathrm{ng}$ of each DNA and $0.4 \mathrm{U}$ of a thermostable AmpliTaq DNA polymerase (Roche). PCR reaction was performed for 35 cycles of denaturation $\left(95^{\circ} \mathrm{C}, 50 \mathrm{~s}\right)$, annealing $\left(62^{\circ} \mathrm{C}, 35 \mathrm{~s}\right)$ and elongation $\left(72^{\circ} \mathrm{C}, 35 \mathrm{~s}\right)$. DNA extracted from $C$. trachomatis (ATCC number: VR-878) was used as positive control.

Two sets of primers, complementary to the early regulatory region of HCMV genome (IEA1 gene) CMV-C/ CMV-D and CMV-A/ CMV-B (Table 1) were used in a nested PCR (36). The reaction mixture $(20 \mu \mathrm{l})$ consisted of $10 \mathrm{mM}$ Tris- $\mathrm{HCl}(\mathrm{pH} 8.3), 50 \mathrm{mM} \mathrm{KCl}, 1.5$ $\mathrm{mM} \mathrm{MgCl}_{2}, 0.25 \mu \mathrm{M}$ of each dNTP, $0.15 \mu \mathrm{M}$ of primers CMV-C and CMV-D in the first reaction and $0.6 \mu \mathrm{M}$ of primers $\mathrm{CMV}-\mathrm{A}$ and $\mathrm{CMV}-\mathrm{B}$ in the second reaction, approximately $100 \mathrm{ng}$ of each DNA and $0.4 \mathrm{U}$ of a thermostable AmpliTaq DNA polymerase (Roche). The first round of PCR with the primer pair CMV-C/ CMV -D was performed for 20 cycles, while the second round of PCR with the primer pair CMV -C/ CMV -D was performed for 30 cycles of denaturation $\left(95^{\circ} \mathrm{C}, 30 \mathrm{~s}\right)$, annealing $\left(53^{\circ} \mathrm{C}, 30 \mathrm{~s}\right)$ and elongation $\left(72^{\circ} \mathrm{C}, 45 \mathrm{~s}\right)$. DNA extracted from Wi-38 (ATCC number: CCL-75) cells infected with HCMV (ATCC number: VR-807) was used as positive control.

AAV 2 was detected in a semi-nested PCR. Two sets of primers R78-1/nest 2 and R781/R78-2 (Table 1) $(37,38)$, complementary to the regulatory region of AAV genome (REP gene), were used. The reaction mixture $(20 \mu \mathrm{l})$ consisted of $10 \mathrm{mM}$ Tris- $\mathrm{HCl}(\mathrm{pH} 8.3), 50 \mathrm{mM}$ $\mathrm{KCl}, 1.5 \mathrm{mM} \mathrm{MgCl} 2,0.2 \mu \mathrm{M}$ of each dNTP, $0.2 \mu \mathrm{M}$ of each primer, approximately $100 \mathrm{ng}$ of each DNA and $0.4 \mathrm{U}$ of a thermostable AmpliTaq DNA polymerase (Roche). The first and 
second round of PCR were performed for 30 cycles of denaturation $\left(95^{\circ} \mathrm{C}, 30 \mathrm{~s}\right)$, annealing $\left(63^{\circ} \mathrm{C}, 30 \mathrm{~s}\right)$ and elongation $\left(72^{\circ} \mathrm{C}, 45 \mathrm{~s}\right)$. Cloned AAV 2 DNA (kindly provided by Dr. J. R. Schlehofer, Heidelberg, Germany) was used as positive control.

PCR conditions for HPV DNA amplification were as previously described (39). Briefly, for HPV screening MY09/MY11 (40) primers were used, while for HPV typing, typespecific primers for HPV 16 and HPV 18 (41) were used (Table 1). DNA isolated from CaSki (ATCC number: CRL-1550) and HeLa cells (ATCC number: CCL-2), which contain integrated HPV 16 and HPV 18 DNA, respectively, were used as positive controls.

Amplified products were resolved by electrophoresis in a $2 \%$ agarose gel stained with ethidium bromide, identified by UV irradiation and photographed (ImageMaster, Pharmacia Biotech).

\section{RESULTS}

The majority of the miscarriages, 102 of $108(94.4 \%)$ occurred during the first trimester of pregnancy, whereas only $6(5.6 \%)$ occurred in the second trimester. Fifty-five $(50.9 \%)$ women miscarried for the first time, 27 (25\%) had one previous miscarriage and 26 $(24.1 \%)$ had two or more previous miscarriages, of which only $12(46.2 \%)$ had more than two consecutive miscarriages, so they can be classified as having recurrent miscarriages (Figure 1).

According to cytogenetic analysis in $16(14.8 \%)$ of 108 samples karyotype could not be determined due to culture failure (insufficient cell growth in 15 cases and one case ofexogenous contamination ). In the remaining 92 samples, 54 (50\%) had normal karyotype and $38(35.2 \%)$ had abnormal karyotype. The most frequently found chromosomal abnormalities were autosomal trisomies in 27 (71 \%) of 38 cases (Table 2). One (3\%) monosomy 21 (karyotype 45,XY,-21), two (5\%) cases of monosomy X, three (8\%) triploidies, three $(8 \%)$ tetraploidies and two $(5 \%)$ mosaicisms were also found (Table 2).

Each DNA sample isolated from placenta of miscarried fetuses was $\beta$-globin positive and thus suitable for further analysis, i.e. detection of $U$. urealyticum, M. hominis, $C$. trachomatis, HCMV, AAV 2 and HPVs by PCR. The results of bacterial and viral DNA detection, by means of PCR, are summarised in Table 3.

To detect the presence of $U$. urealyticum and M. hominis, a semi-nested PCR instead of one step PCR was performed in order to increase sensitivity and specificity of the reaction. However, the presence of either bacterium was not detected in any analysed sample.

The presence of $C$. trachomatis was established in only one (1.0\%) of 108 samples (Table 3). The sample, in which $C$. trachomatis was detected, had normal karyotype and belonged to a patient without previous miscarriages or births, who was impregnated through in vitro fertilization (IVF).

In order to investigate the presence of HCMV and AAV 2, nested and semi-nested PCR were performed. None of the samples contained either virus.

Although no HPV DNA was detected by consensus MY09/MY11 primers, 8 (7.4\%) of 108 samples were positive with type-specific primers for HPV 16 and HPV 18. Two samples were positive for HPV 16 and HPV 18, respectively, while 4 samples were positive for both HPV types (Table 3). 
All HPV positive samples were from women who had miscarriages in the first trimester of pregnancy, 5 of them had 2 or more previous miscarriages, one had 1 previous miscarriage and 2 did not have any previous miscarriages (Table 4). Those with no previous miscarriages were impregnated through IVF procedures. Three of the samples infected with HPV had abnormal, 3 had normal and in 2 cases the karyotype was undetermined.

\section{DISCUSSION}

Although miscarriage represents the most common complication in pregnancy and as such has been thoroughly investigated, the causes of miscarriages are still unexplained in the majority of cases. There are several indications connected to miscarriage, but only genetic and anatomical abnormalities are mostly accepted. Uterine infections are not generally accepted as a cause of miscarriage, since the results of different studies are inconsistent.

There are contradictory results regarding an association of pathogens with the incidence of miscarriage. A number of studies attempted to find a possible connection between miscarriage and bacterial infections in the vagina, with the assumption that such infections could spread to uterus and induce miscarriage. Robertson et al. (42) found a connection between colonisation of vagina with $U$. urealyticum and premature labor, and Donders et al. (7) found that bacterial vaginosis and presence of $U$. urealyticum and $M$. hominis in the vagina were associated with an increased risk of early miscarriage. $U$. urealyticum has also been found in the placenta, associated to perinatal morbidity and mortality and preterm labor $(43,44)$. However, colonisation of the uterine cervix with $U$. urealyticum is quite common in women who did not experience any problem during pregnancy (45), so its possible role in induction of miscarriage is questionable.

According to our previous study of 53 pregnant women, $U$. urealyticum was present in the cervices of $20(38 \%)$ of 53 women, while M. hominis was not detected in any of samples (unpublished data). Furthermore, we also investigated the presence of mycoplasmas in the cervix among 18 women with previous miscarriage, and only U. urealyticum was found in 5 (28\%) women (unpublished data). These observations do not favour the hypothesis that colonisation of cervix with mycoplasmas could be associated with miscarriages. Furthermore, we did not detect either the presence of $U$. urealyticum nor M. hominis in any of 108 samples of the placenta from miscarried fetuses that were analysed herein. There is no doubt in accuracy of these findings, since PCR is a highly sensitive and specific method and it is highly unlikely that an infection remained undetected. Moreover, we amplified the $\beta$-globin gene in all the samples, so the presence of inhibitors of PCR in the samples was also excluded.

$C$. trachomatis and $N$. gonorrhoeae are the most frequent cause of cervicitis. They can ascend to the uterus and ovaries and possibly by vertical transmission to placenta and fetus (46). Indications of involvement of $C$. trachomatis in the development of miscarriage do exist, however there is not enough evidence to confirm them. Stokes and Isada (47) established that C. trachomatis infects placental trophoblast membrane cells in vitro. Study conducted among women undergoing the procedure of IVF implicated a connection between the presence of $C$. trachomatis in cervical scrapings and the failure of implantation and adverse pregnancy outcome (48). In our study we detected $C$. trachomatis in the placenta of a woman that miscarried after IVF, which is concordant with the fact that $C$. trachomatis could infect placental cells in vivo. Since, only $1(1.0 \%)$ of 108 miscarried placenta was positive for $C$. trachomatis, we cannot assume that $C$. trachomatis plays a significant role in the induction of most miscarriages. 
Viral infections of the trophoblast, even with viruses that have little or no pathogenicity, are also considered as possible causes of miscarriage, since they can impair trophoblast function and lead to abnormal implantation and placentation (49). For instance, HCMV is the most common congenital infection in humans. Primary infections with HCMV occur in 0.7 to $4.1 \%$ pregnancies (50), however, whether they have a role in the induction of miscarriage is questionable. Van Lijnschoten et al. (51) emphasize the possibility of HCMV transplacental transfer - they found the presence of pp65, protein of HCMV, in trophoblastic cells in 6.7\% (6/89) cases of spontaneous and induced abortions, but they did not demonstrate that the presence of HCMV is pathogenic for early pregnancy. Transplacental transfer was also confirmed in a mouse model by $\mathrm{Li}$ and Tsutsui (52). Fisher et al. (53) showed that HCMV infects placental trophoblasts and diminishes their normal function, which could lead to miscarriage. However, herein, we did not detect HCMV DNA in any of the samples, and our results do not support the hypothesis that HCMV might play a role in the induction of miscarriage.

AAVs are human helper virus-dependent parvoviruses, which require helper viruses for their replication. Adenoviruses, herpes viruses, vaccinia virus and HPVs have been identified as helper viruses for AAV $(26,54)$. According to several studies AAV DNA has been detected in placental tissue of human origin $(25,27)$. The virus is widespread in the population, but without any obvious pathogenic effect (55). AAV 2 is the most frequent AAV type infecting the human population (38). Botquin et al. (56) established that infection of pregnant mice with AAV 2 induced fetal death and early abortion. Kiehl et al. (57) detected AAV DNA in 11 (73\%) of 15 samples from spontaneous abortion. However, they did not detect HCMV in any of the samples, while HPV was detected in only one sample of spontaneous abortion. On the other hand, Friedman-Einat et al. (58) analysed a number of clinical samples of different origin, among which 62 samples were from first trimester abortions (38 spontaneous and 24 induced abortions). They did not find AAV DNA in any of aborted material samples, although they found the presence of AAV DNA in $18 \%$ of genital swab samples. Our findings are in concordance with results of the Friedman-Einat et al. study (58), as we did not detect AAV DNA in any placentas from spontaneously aborted fetuses. Because there is a large discordance in different studies performed so far, further investigations are required. One possible explanation for such discrepancies in detection of AAV in cervical scrapings could be different prevalence of AAV infection in different populations, which was proposed by Venturoli et al. (59).

An increase of HPV during pregnancy has been observed (60) and its transplacental transfer has been proposed by some authors (61), but also disputed by others (62). However, Hermonat et al. (29) found that HPV prevalence in placentas from first trimester miscarriages was as high as $60 \%$ compared to $20 \%$ prevalence in electively aborted fetuses. In their 1998 study, conducted on the subset of paraffin-embedded tissue from their previous study, Hermonat et al. (30) determined that the preferential site of HPV infection was syncytiotrophoblast and since trophoblasts maintain placental contact with maternal tissue, they assumed that altered characteristics of HPV-infected trophoblasts might lead to miscarriage. The results of the Liu et al. (63) study showed that HPV16 carries out its complete life cycle in cultured placental trophoblasts, which is in concordance with the aforementioned study. Contrary to that in the Sifakis et al. (64) study no HPV DNA was detected in spontaneously aborted material.

Malhomme et al. (27) examined 26 paraffin sections from uterine biopsies and early misscarriage that contained AAV for the presence of AAV helper viruses adenovirus, HSV and HCMV. They did not find the presence of these viruses in any of the samples, but they did find HPV DNA in $60 \%$ samples from uterine biopsies and approximately $70 \%$ of early 
miscarriage samples. Armbruster-Moraes et al. (65) also detected HPV in $64.9 \%$ (24/37) of amniotic fluid samples taken from pregnant women with cervical lesions indicative for HPV infection. Furthermore, Eppel et al. (66) conducted a study of HPV infection on chorionic villi and placental biopsies taken for the purpose of genetic analysis after the twentieth week of pregnancy. They found $24.6 \%$ (44/179) HPV infection rate in the cervices of women, but did not find HPV in any of 147 placentas and chorionic villi examined. The difference in detection of HPV in the aborted tissue found in different studies is very puzzling, as it varies from 0 to $70 \%$.

Herein, we found the presence of HPV DNA in $7.4 \%$ of miscarriage specimens, which does not point toward a major role of HPV infection in the induction of miscarriages, but it confirms the possibility of its transplacental transfer. Also, since the infection was found in three samples that had abnormal karyotype and additional two samples with undetermined karyotype, further investigations of a possible association between HPV infection and development of genetic abnormalities during embryogenesis would be in order, at least on animal model, since it is established that HPV is the cause of genetic instabilities which result with the development of various types of complex chromosomal abnormalities in malignant tumor cells (28). It should also be noted that, by using consensus primers (MY09/MY11), which recognise L1 region of HPV genome, we did not detect HPV in any of placental samples, although by using type-specific primers for HPV 16 and HPV 18, HPV infection was detected in 8 samples. This could be due to greater sensitivity of type-specific primers, in case of low copy number of viral genome in the analyzed material (39). Another explanation could be that HPV 16 and HPV 18, which are frequently integrated in the genome of cervical cells, are also integrated into the cell genome of placental cells (not investigated herein), and as such could be involved in the development of genetic abnormalities of the placenta and/or the fetus. Our results show that the number of HPV positive samples is proportionally higher in the group of women with two or more previous miscarriages, but it is not possible to conduct statistical analysis due to small number of samples and low expectancy values.

The possibility of sample contamination with cervical cells is not excluded, since the samples were acquired during curettage and they passed through cervix and vagina. However, in that case we would expect to detect other pathogens that are common inhabitants of the cervix and vagina, i.e. C. trachomatis (detected only in 1 sample herein), U. urealyticum and $M$. hominis (not detected herein). In this study, only one placental sample was contaminated by exogenous infection during cell cultivation for karyotyping, which can be the consequence of contamination with pathogens commonly found in the surroundings. So, the fact that we did not detect other pathogens by PCR, points to the conclusion that the HPV positive findings in the placenta are not the consequence of the contamination during the passage through cervical canal, but indeed HPV infection of the placenta.

Although the results of our study do not confirm a role of $C$. trachomatis, $U$. urealyticum, $M$. hominis, HCMV and AAV infections as a cause of miscarriages in the first trimester of pregnancy, the role of additional infections could not be excluded. Thus HPV infections, found herein in $7.4 \%$ cases, necessitate further investigation. 


\section{REFERENCES}

1. Zinaman MJ, Clegg ED, Brown CC, O’Connor J, Selevan SG. Estimates of human fertility and pregnancy loss. Fertil Steril 1996;65:503-9.

2. Edmonds DK, Lindsay KS, Miller JF, Williamson E, Wood PJ. Early embrionic mortality in women. Fertil Steril 1982;38:447-53.

3. Wolf GC, Horger EO. Indications for examination of spontaneous abortion specimens: a reassessment. Am J Obstet Gynecol 1995;173:1364-8.

4. Ogasawara M, Aoki K, Okada S, Suzumori K. Embryonic karyotype of abortuses in relation to the number of previous miscarriages. Fertil Steril 2000;73:300-4.

5. Grimbizis GF, Camus M, Tarlatzis BC, Bontis JN, Devroey P. Clinical implications of uterine malformations and hysteroscopic treatment results. Hum Reprod Update 2001;7:161-74.

6. Daya S, Ward S, Burrows E. Progesterone profiles in luteal phase defect cycles and outcome of progesterone treatment in patients with recurrent spontaneous abortion. Am $\mathrm{J}$ Obstet Gynecol 1988;158:225-32.

7. Donders GG, Van Bulck B, Caudron J, Londers L, Vereecken A, Spitz B. Relationship of bacterial vaginosis and mycoplasmas to the risk of spontaneous abortions. Am J Obstet Gynecol 2000;183:431-7.

8. Garcia-Enguinados A, Calle ME, Valero J, Luna S, Dominguez-Rojas V. Risk factors in miscarriage: a review. Eur J Obstet Gynecol Reprod Biol 2002;102:111-9.

9. McDonald HM, Chambers HM. Intrauterine infection and spontaneous midgestation abortion: is the spectrum of microorganisms similar to that in preterm labor? Infect Dis Obstet Gynecol 2000;8:220-7.

10. Gibbs RS. Chorioamnionitis and bacterial vaginosis. Am J Obstet Gynecol 1993;169:4602.

11. Gauthier DW, Meyer WJ, Bieniarz A. Expectant management of premature rupture of membranes with amniotic fluid cultures positive for Ureaplasma urealyticum alone. Am $\mathrm{J}$ Obstet Gynecol 1994;170:587-90.

12. McDonald HM, O'Loughlin JA, Jolley PT, Vigneswaran R, McDonald PJ. Changes in vaginal flora during pregnancy and association with preterm birth. $\mathrm{J}$ Infect Dis 1994;170:724-8.

13. Robboy SJ, Duggan MA, Kurman RJ. The female reproductive system. In: Farber RE, eds. Pathology. Philadelphia: JB Lippincott, 1994:962-7.

14. Goldenberg RL, Hauth JC, Andrews WW. Intrauterine infection and preterm delivery. N Engl J Med 2000;342:1500-7.

15. Witkin SS, Sultan KM, Neal GS, Jeremias J, Grifo JA, Rosenwaks Z. Unsuspected Chlamydia trachomatis infection and in vitro fertilization outcome. Am J Obstet Gynecol 1994;171:1208-14.

16. Martin DH, Koutsky L, Eschenbach DA, Daling JR, Alexander ER, Benedetti JK et al. Prematurity and perinatal mortality in pregnancies complicated by maternal Chlamydia trachomatis infections. JAMA 1982;247:1585-8.

17. McCormack WM, Almeida PC, Bailey PE, Grady EM, Lee YH. Sexual activity and vaginal colonization with genital mycoplasmas. JAMA 1972;221:1375-7.

18. Kundsin RB, Driscoll SG, Ming PL. Strain of mycoplasma associated with human reproductive failure. Science 1967;157:1573-4.

19. Sompolinsky D, Solomon F, Elkina L, Weinraub Z, Bukovsky I, Caspi E. Infections with mycoplasma and bacteria in induced midtrimester abortion and fetal loss. Am J Obstet Gynecol 1975;121:610-6. 
20. Stagno S, Pass RF, Dworsky ME, Henderson RE, Moore EG, Walton PD et al. Congenital cytomegalovirus infection: The relative importance of primary and recurrent maternal infection. N Engl J Med 1982;306:945-9.

21. Putland RA, Ford J, Korban G, Evdokiou A, Tremaine M. Investigation of spontaneously aborted concepti for microbial DNA: investigation for cytomegalovirus DNA using polymerase chain reaction. Aust N Z J Obstet Gynaecol 1990;30:248-50.

22. Cook SM, Himebaugh KS, Frank TS. Absence of cytomegalovirus in gestational tissue in recurrent spontaneous abortions. Diagn Mol Pathol 1993;2:116-9.

23. Berns KI, Bohenzky RA. Adeno-associated viruses: an update. Adv Virus Res 1987;32:243-306.

24. Grossman Z, Mendelson E, Broksimoni F, Mileguir F, Leitner Y, Rechavi G et al. Detection of adeno-associated virus type 2 in human peripheral blood cells. J Gen Virol 1992;73:961-6.

25. Tobiasch E, Rabreau M, Geletneky K, Larue-Charlus S, Severin F, Becker N et al.. Detection of adeno-associated virus DNA in human genital tissue and material from spontaneous abortion. J Med Virol 1994;44:215-22.

26. Walz C, Deprez A, Dupressoir T, Durst M, Rabreau M, Schlehofer JR. Interaction of human papillomavirus type 16 and adeno-associated virus type 2 co-infecting human cervical epithelium. J Gen Virol 1997;78:1441-52.

27. Malhomme O, Dutheil N, Rabreau M, Armbruster-Moraes E, Schlehofer JR, Dupressoir T. Human genital tissues containing DNA of adeno-associated virus lack DNA sequences of the helper viruses, adenovirus, herpes simplex virus or cytomegalovirus but frequently contain human papillomavirus DNA. J Gen Virol 1997;78:1957-62.

28. zur Hausen H. Papillomaviruses and cancer: from basic studies to clinical application. Nat Rev Cancer 2002;2:342-50.

29. Hermonat PL, Han L, Wendel PJ, Quirk JG, Stern S, Lowery CL et al. Human papillomavirus is more prevalent in first trimester spontaneously aborted products of conception compared to elective specimens. Virus Genes 1997;14:13-7.

30. Hermonat PL, Kechelava S, Lowery CL, Korourian S. Trophoblasts are the preferential target for human papilloma virus infection in spontaneously aborted products of conception. Human Pathology 1998;29:170-4.

31. Singer Z, Profeta K. Chorion frondosum cultivation in antenatal detection of genetic disease. Period Biol 1989;91:77-78.

32. Sambrook J, Fritsch EF, Maniatis T (1989) Molecular cloning: a laboratory manual, Cold Spring Harbor Laboratory Press, CSH, New York.

33. Bell DA, Taylor JA, Paulson DF, Robertson CN, Mohler JL, Lucier GW. Genetic risk and carcinogen exposure: a common inherited defect of the carcinogen-metabolism gene glutathione S-transferase M1 (GSTM1) that increases susceptibility to bladder cancer. J Natl Cancer Inst 1993;85:1159-64.

34. Abele-Horn M, Wolff C, Dressel P, Zimmermann A, Vahlensieck W, Pfaff F et al. Polymerase chain reaction versus culture for detection of Ureaplasma urealyticum and Mycoplasma hominis in the urogenital tract of adults and respiratory tract of newborns. Eur J Clin Microbiol Infect Dis 1996;15:595-8.

35. Loeffelholz MJ, Lewinski CA, Silver SR, Purohit AP, Herman SA, Buonagurio DA et al. Detection of Chlamydia trachomatis in endocervical specimens by polymerase chain reaction. J Clin Microbiol 1992;30:2847-51.

36. Brytting M, Sundqvist VA, Stalhandske P, Linde A, Wahren B. Cytomegalovirus DNA detection of an immediate early protein gene with nested primer oligonucleotides. J Virol Methods 1991;32:127-38. 
37. Han L, Parmley TH, Keith S, Kozlowski KJ, Smith LJ, Hermonat PL. High prevalence of adeno-associated virus (AAV) type 2 rep DNA in cervical materials: AAV may be sexually transmitted. Virus Genes 1996;12:47-52.

38. Tobiasch E, Burguete T, Klein-Bauernschmitt P, Heilbronn R, Schlehofer JR. Discrimination between different types of human adeno-associated viruses in clinical samples by PCR. J Virol Methods 1998;71:17-25.

39. Husnjak K, Grce M, Magdic L, Pavelic K. Comparison of five different polymerase chain reaction methods for detection of human papillomavirus in cervical cell specimens. J Virol Methods 2000;88:125-34.

40. Manos MM, Ting Y, Wright DK, Lewis AI, Broker TR, Wolinsky SM. The use of polymerase chain reaction amplification for the detection of genital human papillomaviruses. Cancer Cells 1989;7:209-14.

41. Soler C, Allibert P, Chardonnet Y, Cros P, Mandrand B, Thivolet J. Detection of human papillomavirus types $6,11,16$ and 18 in mucosal and cutaneous lesions by the multiplex polymerase chain reaction. J Virol Methods 1991;35:143-57.

42. Robertson JA, Honore LH, Stemke GW. Serotypes of Ureaplasma urealyticum in spontaneous abortion. Pediatr Infect Dis 1986;5:S270-2.

43. Kundsin RB, Driscoll SG, Pelletier PA. Ureaplasma urealyticum incriminated in perinatal morbidity and mortality. Science 1981;213:474-6.

44. Kundsin RB, Leviton A, Allred EN, Poulin S. Ureaplasma urealyticum infection of the placenta in pregnancies that ended prematurely. Obstet Gynecol 1996;87:122-7.

45. Abele-Horn M, Wolff C, Dressel P, Pfaff F, Zimmermann A. Association of Ureaplasma urealyticum biovars with clinical outcome for neonates, obstetric patients, and gynecological patients with pelvic inflammatory disease. J Clin Microb 1997;35:1199202.

46. Kumar V, Cotran R, Robbins S, eds. Basic Pathology. Fifth Edition. Philadelphia: W.B Saunders Company, 1992.

47. Stokes GV, Isada NB. Albumin enhances chlamydial infectivity on human placental cells Microbios 1991;65:179-86.

48. Witkin SS, Kligman I, Grifo JA, Rosenwaks Z. Chlamydia trachomatis detected by polymerase chain reaction in cervices of culture-negative women correlates with adverse in vitro fertilization outcome. J Infect Dis 1995;171:1657-9.

49. Arechavaleta-Velasco F, Koi H, Strauss JF 3rd, Parry S. Viral infection of the trophoblast: time to take a serious look at its role in abnormal implantation and placentation? J Reprod Immunol 2002;55:113-21.

50. Demmler GJ. Infectious Diseases Society of America and Centers for Disease Control. Summary of a workshop on surveillance for congenital cytomegalovirus disease. Rev Infect Dis 1991;13:315-29.

51. van Lijnschoten G, Stals F, Evers JL, Bruggeman CA, Havenith MH, Geraedts JP. The presence of cytomegalovirus antigens in karyotyped abortions. Am J Reprod Immunol 1994;32:211-20.

52. Li RY, Tsutsui Y. Growth retardation and microcephaly induced in mice by placental infection with murine cytomegalovirus Teratology 2000;62:79-85.

53. Fisher S, Genbacev O, Maidji E, Pereira L. Human cytomegalovirus infection of placental cytotrophoblasts in vitro and in utero: implications for transmisson and pathogenesis. $\mathrm{J}$ Virol 2000;74:6808-20.

54. Schlehofer JR, Ehrbar M, zur Hausen H. Vaccinia virus, herpes simplex virus, and carcinogens induce DNA amplification in a human cell line and support replication of a helpervirus dependent parvovirus. Virology 1986;152:110-7. 
55. Erles K, Sebokova P, Schlehofer JR. Update on the prevalence of serum antibodies (IgG and IgM) to adeno-associated virus (AAV). J Med Virol 1999;59:406-11.

56. Botquin V, Cid-Arregui A, Schlehofer JR. Adeno-associated virus type 2 interfers with early development of mous embryos. J Gen Virol 1994;75:2655-62.

57. Kiehl K, Schlehofer JR, Schultz R, Zugaib M, Armbruster-Moraes E. Adeno-associated virus DNA in human gestational trophoblastic disease. Placenta 2002;23:410-5.

58. Friedman-Einat M, Grossman Z, Mileguir F, Smetana Z, Ashkenazi M, Barkai G et al. Detection of adeno-associated virus type 2 sequences in the human genital tract. J Clin Microbiol 1997;35:71-8.

59. Venturoli S, Cricca M, Bonvicini F, Gallinella G, Gentilomi G, Zerbini M et al. Detection of adeno-associated virus DNA in female genital samples by PCR-ELISA. J Med Virol 2001;64:577-82.

60. Fife KH, Katz BP, Roush J, Handy VD, Brown DR, Hansell R. Cancer-associated human papillomavirus types are selectively increased in the cervix of women in the first trimester of pregnancy. Am J Obstet Gynecol 1996;174:1487-93.

61. Puranen MH, Yliskoski MH, Saarikoski SV, Syrjanen KJ, Syrjanen SM. Exposure of an infant to cervical human papillomavirus infection of the mother is common. Am J Obstet Gynecol 1997;176:1039-45.

62. Watts DH, Koutsky LA, Holmes KK, Goldman D, Kuypers J, Kiviat NB. Low risk of perinatal transmission of human papillomavirus: results from a prospective cohort study. Am J Obstet Gynecol 1998;178:365-73.

63. Liu Y, You H, Chiriva-Internati M, Korourian S, Lowery CL, Carey MJ et al. Display of complete life cycle of human papillomavirus type 16 in cultured placental trophoblasts. Virology 2001;290:99-105.

64. Sifakis S, Ergazaki M, Sourvinos G, Koffa M, Koumantakis E, Spandidos DA. Evaluation of Parvo B19, HCMV and HPV viruses in human aborted material using the polymerase chain reaction technique. Eur J Obstet Gynecol Reprod Biol 1998;76:169-73.

65. Armbruster-Moraes E, Ioshimoto LM, Leao E, Zugaib M. Presence of Human papillomavirus DNA in amniotic fluids of pregnant women with cervical lesions. Gynecol Oncol 1994;54:152-8.

66. Eppel W, Worda C, Frigo P, Ulm M, Kucera E, Czerwenka K. Human papillomavirus in the cervix and placenta. Obstet Gynecol 2000;96:337-41. 

Table 1 List of oligonucleotides used in this study

\begin{tabular}{|c|c|c|c|c|}
\hline Microorganism & Primer & $5 ’-3$ & Size (bp) & References \\
\hline \multirow{3}{*}{ M. hominis } & M1 & CAA TGG CTA ATG CCG GAT ACG C & \multirow{3}{*}{$\begin{array}{c}\text { M1/M2: } 335 \\
\text { M2/RNAH3: } 284\end{array}$} & \multirow{3}{*}{ Abele-Horn et al. (34) } \\
\hline & M2 & GGT ACC TGC AGT CTG CAA T & & \\
\hline & RNAH3 & CGC TGT AAG GCG CAC RAA A & & \\
\hline \multirow{3}{*}{ U. urealyticum } & $\mathrm{U} 4$ & ACG ACG TCC ATA AGC AAC T & \multirow{3}{*}{$\begin{array}{l}\text { U4/U5: } 430 \\
\text { U4/U9: } 258\end{array}$} & \multirow{3}{*}{ Abele-Horn et al. (34) } \\
\hline & U5 & CAA TCT GCT CGT GAA GTA TTA C & & \\
\hline & U9 & GAG ATA ATG ATT ATA TGT CAG GAT CA & & \\
\hline \multirow{2}{*}{ C. trachomatis } & $\mathrm{CP} 24$ & GGGATTCCTGTAACAACAAGTCAGG & \multirow{2}{*}{207} & \multirow[t]{2}{*}{ Loeffelholz et al. (35) } \\
\hline & $\mathrm{CP} 27$ & ССТСТТССССAGAACAATAAGAACAC & & \\
\hline \multirow{4}{*}{ HCMV } & $\mathrm{C}$ & TGAGGATAAGCGGGAGATGT & \multirow{4}{*}{242} & \multirow{4}{*}{$\begin{array}{l}\text { Brytting et al. } \\
\text { (36) }\end{array}$} \\
\hline & $\mathrm{D}$ & ACTGAGGCAAGTTCTGCAGT & & \\
\hline & A & AGCTGCATGATGTGAGCAAG & & \\
\hline & $\mathrm{B}$ & GAAGGCTGAGTTCTTGGTAA & & \\
\hline \multirow{3}{*}{ AAV 2} & NEST2 & AGT TCA AAT TTG AAC ATC CGG TC & \multirow{3}{*}{$\begin{array}{c}\text { R78-1/NEST2: } 324 \\
\text { R78-1/R78/2: } 221\end{array}$} & \multirow{3}{*}{$\begin{array}{c}\text { Han et al. (37) } \\
\text { Tobiasch et al. (38) }\end{array}$} \\
\hline & $\mathrm{R} 78-1$ & CAT CGC GGA GGC CAT AGC CC & & \\
\hline & $\mathrm{R} 78-2$ & ACG GGA GTC GGG TCT ATC TG & & \\
\hline \multirow{6}{*}{ HPV } & MY11 & GCM CAG GGW CAT AAY AAT GG * & \multirow{2}{*}{$\sim 450$} & \multirow{2}{*}{ Manos et al. (40) } \\
\hline & MY09 & CGT CCM ARR GGA WAC TGA TC * & & \\
\hline & HPV 16-F & CCC AGC TGT AAT CAT GCA TGG AGA & \multirow{2}{*}{253} & \multirow{4}{*}{ Soler et al. (41) } \\
\hline & HPV 16-R & GTG TGC CCA TTA ACA GGT CTT CCA & & \\
\hline & HPV 18-F & CGA CAG GAA CGA CTC CAA CGA & \multirow{2}{*}{201} & \\
\hline & HPV 18-R & GCT GGT AAA TGT TGA TGA TTA ACT & & \\
\hline
\end{tabular}

* $\mathrm{M}=\mathrm{A}+\mathrm{C}, \mathrm{R}=\mathrm{A}+\mathrm{G}, \mathrm{W}=\mathrm{A}+\mathrm{T}, \mathrm{Y}=\mathrm{C}+\mathrm{T}$ 
Table 2 Types of genetic abnormalities found in the study group $(\mathrm{N}=38)$

\begin{tabular}{ccc}
\hline Type of abnormality & $\begin{array}{c}\text { Chromosomes } \\
\text { involved / karyotype }\end{array}$ & $\begin{array}{c}\text { Number of } \\
\text { cases }\end{array}$ \\
\hline & 2 & 1 \\
& 5 & 2 \\
& 7 & 2 \\
Trisomy & 8 & 1 \\
& 9 & 1 \\
& 13 & 4 \\
& 15 & 2 \\
& 16 & 1 \\
& 17 & 3 \\
& 21 & 1 \\
& 22 & 4 \\
Monosomy 21 & 21 & 4 \\
Monosomy X & X & 1 \\
Triploidy & whole set & 3 \\
Tetraploidy & whole set & 3 \\
Mosaicism & 46, XX/92XXXX & 1 \\
& 46, XX/69,XXY & 1 \\
\hline
\end{tabular}

Table 3 The presence of bacterial or viral DNA in aborted placental tissue (N=108)

\begin{tabular}{ccccccc}
\hline \multirow{2}{*}{ Microorganism } & \multicolumn{2}{c}{ Normal karyotype } & \multicolumn{2}{c}{ Abnormal karyotype } & \multicolumn{2}{c}{$\begin{array}{c}\text { Undetermined } \\
\text { karyotype }\end{array}$} \\
\cline { 2 - 7 } & positive & negative & positive & negative & positive & negative \\
\hline U. urealyticum & 0 & 54 & 0 & 38 & 0 & 16 \\
M. hominis & 0 & 54 & 0 & 38 & 0 & 16 \\
C. trachomatis & 1 & 53 & 0 & 38 & 0 & 16 \\
AAV 2 & 0 & 54 & 0 & 38 & 0 & 16 \\
HCMV & 0 & 54 & 0 & 38 & 0 & 16 \\
HPV & 3 & 51 & 3 & 35 & 2 & 14 \\
\hline
\end{tabular}


Table 4 Samples positive for the presence of high risk HPV DNA

\begin{tabular}{ccclccccc}
\hline Sample & Age & $\begin{array}{c}\text { Gestational } \\
\text { week }\end{array}$ & \multicolumn{1}{c}{ Karyotype } & $\begin{array}{c}\text { Number of live } \\
\text { births }\end{array}$ & $\begin{array}{c}\text { Number of } \\
\text { miscarriages }\end{array}$ & Comments & HPV16 & HPV18 \\
\hline 1 & 26 & 7 & $46, \mathrm{XX}$ & 3 & 2 & & - & + \\
2 & 36 & 10 & $46, \mathrm{XX}$ & 1 & 2 & & + & + \\
3 & 32 & 9 & ND $*$ & 1 & 4 & & + & + \\
4 & 25 & 10 & $92, \mathrm{XXYY}$ & 0 & 2 & & + & + \\
5 & 25 & 5 & $46, \mathrm{XX}$ & 0 & 0 & IVF $\dagger$ & + & + \\
6 & 30 & 8 & ND $*$ & 1 & 2 & $\mathrm{CIN} \mathrm{III}+$ & - & + \\
7 & 35 & 8 & $47, \mathrm{XY},+22$ & 0 & 1 & & + & - \\
8 & 35 & 10 & $47, \mathrm{XY}+9$ & 1 & 0 & IVF $\dagger$ & + & - \\
\hline
\end{tabular}

$*$ ND, not determined; $\uparrow$ IVF, in vitro fertilisation; $\$$ CIN III, cervical intraepithelial neoplasia grade III



Figure 1 Number of previous miscarriages in the study population (N108)

0 - no previous miscarriages; 1 - one previous miscarriage; 2 - two or more previous miscarriages 